\title{
Entrepreneurship Development through Tourism Villages in the Perspective of Defense Economic (Study Case: Penting Sari, Sleman, Yogyakarta)
}

\section{Andhika Alfathanah Putra Pandu Pratama1, Supandi Halim², Sulistiyanto ${ }^{3}$ and Dony Setiawan $^{4}$}

\author{
${ }^{1}$ Indonesia Defense University, Indonesia \\ ${ }^{2}$ Indonesia Defense University, Indonesia \\ ${ }^{3}$ Indonesia Defense University, Indonesia \\ ${ }^{4}$ Indonesia Defense University, Indonesia
}

\begin{abstract}
This article provides one of successful village, which able transformation from poor village to destination tourism. Entrepreneurship is the success key of Pentingsari Village as a tourism village. Pentingsari Village Tourism offering circumstances nature. Living in the village is rarely activity for people who live in the city. Atmosphere environment in Pentingsari Village is natural healing of overfullness activity in the city. Indirectly, entrepreneurship based on tourism village is connected with economic defense concept. Economic defense concept put society as the first defense basis. Society as a primary actor, in activity tourism village. This paper uses a qualitative method, we are doing observation to Pentingsari Village Tourism, focus group discussion and deep interview with resident and also head of village. In the end of the day, the Indonesian government must contrive some regulations to provide all parties involved to maximize the potential of village in every region in Indonesian territory.
\end{abstract}

Keywords : Entrepreneurship, Tourism, Economics Defense

\section{Introduction}

Poverty is a problem faced by various countries in all over the world. One of the causes of poverty is an uneven development (e.g. Infrastructure and human resources). In addition, poverty brings out an uncertainty of economic condition in a country. This is due to people purchasing power tends to be low. United Nations (UN) has a long-term planning through Millennium Development Goals (MDGs). MDGs is a UN work agenda in order to build a better life for most vulnerable in this world. MDGs has 8 (eight) agenda points to provide vast new opportunities for better lives. The first point is Eradicate Extreme Poverty \& Hunger.

Furthermore, in order to support the MDGs work program, UN issued the SDGs (Sustainable Development Goals), namely sustainable development work agenda, so that the MDGs work program can be achieved. SDGs have 17 (seventeen) work programs, which poverty is the main focus in achieving a better future of human life. The Indonesian government through Bappenas (National Development Planning Agency), MDGs and SDGs are a reference for Bappenas to run Indonesia's development evenly. In addition, The President of Indonesia, Ir. H. Joko Widodo, has nine work programs called NAWACITA to create justice for all Indonesians.

In realizing equitable development, Indonesian government seeks to develop its country start from the periphery to center. This is due to the fact that the infrastructure that is located on the edge of the city has not yet been built optimally, so that it is difficult for people to get access to education, health, and distribution of goods and services. Therefore, infrastructure development is the main agenda of the current Indonesian government, especially from the eastern part of Indonesia. Previously, Indonesia's development focused on the island of Java. At present, Indonesian government is trying to build all over region in Indonesia, starting from border area, as well as eastern Indonesia. This is the mandate of the constitution and the 1945 Constitution of the Republic of Indonesia in realizing social justice for all Indonesian. 
In 2018, Indonesian government has an agenda to develop its human resources. One of the Indonesian strategies based on it by open vocational school, training management program, and also entrepreneurship program. Entrepreneurship program is a method to create a new economy sector, and to open wider opportunity of employment. United States has entrepreneurs with its percentages about 3\% from the total of US population. Whereas in Southeast Asian countries, such as Thailand and Malaysia, the number of entrepreneurs is $1 \%-2 \%$ of the total population. And Indonesia is about $0.001 \%$. Ideally, the total population in a country, the percentage of entrepreneurs should be about $1 \%-3 \%$.

Entrepreneurs have an important role in the economy of a county. Entrepreneurship is one of various methods to added value in an item, or to utilize something has a potential to be developed. Entrepreneurs become one of the government programs to do many kinds of production activities. This is to improve the economy production in Indonesia both in the micro and macro sectors. At present, the world is entering the era of Industrial Revolution 4.0, where all human activities can be carried out wherever and whenever they are. This is due to technological advances. One example, namely internet is a technology that can help all human business activities through a smartphone. Furthermore, wireless connection, is the identity of the industrial revolution 4.0 era.

Entrepreneurs see the industrial revolution 4.0 as a momentum to create a new economic sector, including creative industry and digital economy. Creative industries have multiple added values, because they utilize all the resources they have. Tourism is one example in a creative industry, tourism is not only about tourist areas, but also about a destination or tourism destination. Pentingsari Tourism Village, Umbulharjo, Cangkringan, Sleman Regency, DIY (Yogyakarta Special Region) is one of the examples of it. It established because this village is located in an isolated area. The community in that village does not have access to leave its village to get an opportunity in economic activities outside of the village.

Pentingsari is a village that have a high number of poor people, and they are unable to send their children to school or continue their education. Furthermore, there is always one of the sons of the region who came from Pentingsari Village to continue their education. After they graduates, they must return to its village in order to build and develop their own village. In developing this village, Pentingsari tries to create a village daily activity that can be used as a tourism destination.

In 2008, Pentingsari is restructured its management. The government and related parties try to plan the future of its village. The approach used is village-based entrepreneurship. In addition, Pentingsari is surrounded by tourism destinations which is located in Sleman-DIY Regency. Thus, Pentingsari Village transformed into a tourist destination for domestic and foreign tourists. This is because Pentingsari Village offers a variety of village activity activities, such as tourists can be participated in becoming villagers.

Theory of Tourism Development. The concept of development is an idea, design, which can produce an innovation and can provide positive advantages if it is applied to all various sectors. Some of them is; HR development, tourism, curriculum, and region. The concept of tourism and regional development is a focus from this theory. A development concept is an activity to create something new and bring it into an innovation. Thus, it is able to have capabilities and solutions. Ady (2015) states that tourism activities can be implemented in farming villages. Tourism development begins with mapping in an area covering region, district, and city. After the mapping has been carried out, the potential possessed by the region through economic indicators can be seen as one of the tourism category potentials.

Then, after determining the potential, it developed into a new tourism by build a new Infrastructure so that village can be connected with the others. Furthermore, there is a development model by various tourism experts, one of Gunn's tourism experts, Gunn has a tourism development model through nine external factors, which influence the development of tourism, including; natural resources, cultural resources, leadership and organization, finance, labor, entrepreneurship, society, competence, and government policies. The tourism development model developed by Gunn can be seen as below: 


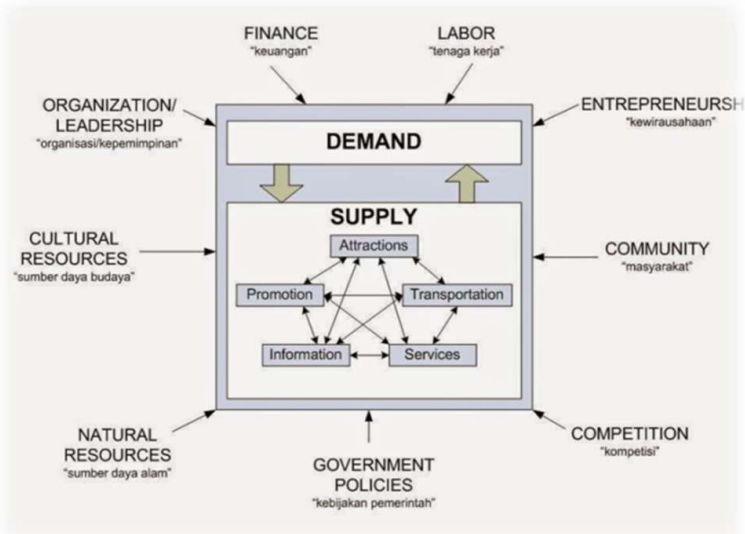

Picture 1. Tourism Development of Gunn (2002)

This tourism development stated by Gunn, explains that external factors have implications for the tourism transformation in an area. Therefore, in line with economic theory, that supply, and demand are the keys of tourism development. Supply and demand are the basis of microeconomic theory. Tourism development cannot be realized yet, if there is no demand and supply at the same position. This point is called market balance or equilibrium. Therefore, the basis of tourism development, stems from microeconomic studies. Leiper also tried to connect infrastructure with tourism destinations. Thus, it is very important to facilitate a road to the village in order to mobilize tourists. Therefore, roads, infrastructure and public facilities must be built. Through the Leiper development model, the relationship between tourists and tourism managers can be created well, if policy makers or the government are able to identify the needs of tourism development. Leiper describes the tourism development model, as below:

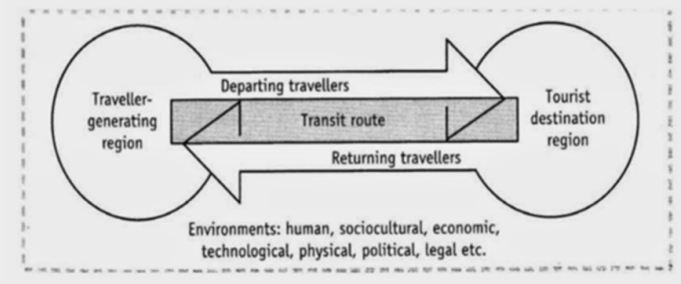

Picture 2. Tourism development of Leiper (2010)

Leipier describes, if connectivity between tourism destinations and tourists can be connected, there will be various assimilation with the environment, people, economics, socio-cultural, technological transfer and politics. Thus, a holistic development is created through tourism development. When looking at the two development models above, everyone has their own approach in developing tourism models depending on their perspectives. Therefore, the tourism development model is dynamic tourism which can be developed and can be seen from any different angle. In this study, among the two models of tourism development above, the researcher will use a development model 
that has been initiated by Gunn. Researcher tries to combine between tourism stakeholders and tourism development for the village prosperity.

Theory of Defense Economy. Defense Economy has two different syllables; economy and defense. Economy is a way to utilize limited resources, with unlimited human desires, and maximize profits, with minimal effort. Defense science is a systematic knowledge in the principles of war and/or defense, systematic development, examination, or evaluation of the results of analysis, appropriate methods of dissemination and understanding of the capabilities possessed.

Furthermore, defense is a concept; efforts to maintain by using or utilizing all the resources that are owned in order to face any various threats. Therefore, defense is an effort to maintain sovereignty. There are three approaches in understanding defense; defense science through ontology view, epistemology, and defense science can be reviewed through axiology perspective.

Economy and defense can be combined into defense economy. It is a method, to manage various resources owned by a country, for integrity and sovereignty of the state. Therefore, the Defense Economy is present to realize the independence of a nation. There is another opinion about the defense economy, Sapolsky explained, that the defense sector is a business. This is related to the defense budget. Therefore, the defense economy will not work, if there is no financial support from the government, to finance national defense.

In addition, the defense economy has a concept to support the national defense system. There are two main conditions if a nation wants to build a strong national defense; welfare and security . If economy of the people is fulfilled, there are no conflicts or disputes among them. After the realization of income equality, automatically, security will be achieved. This is because of basic human needs have been fulfilled. Therefore, the key of achieving national defense is that the government must be able to improve its economic justice for the citizen.

There are three pillars that form the basis of the defense economics discipline. First; economic law, second; political economy, and third; economic politics. Those three bases of defense economics are the key to create a self-sustaining state economy and are not dependent on other countries. Economy law is the umbrella of laws in doing national economy activities. The legal foundation of the Indonesian economy lies in Pancasila and the 1945 Constitution. The fifth precept reads "social justice for all Indonesians". Therefore, the government must provide economic justice broadly.

The 1945 Constitution article 33 paragraph (1) explains that, the economy is arranged as a joint effort based on the principle of family. Furthermore, in paragraph (4), the national economy is carried out based on the principles of economic democracy with principles, togetherness, efficiency in justice, independence, and maintaining balance.

Political economy is a scientific base, as well as a study of interrelations that are correlated between one and another, and It has an ability to influence both economic factors and political factors. The five variables are indicators or benchmarks for a country's political economy.

These variables include: 1 . Government intervention, policy changes, political economic actions, 2 . Price increases in the market, 3. Declining purchasing power, 4. Scarcity of resources, 5. Social revolution, industrial transformation, 6 . Revolution and advances in science, knowledge, technology, communication and information. Political economy is Das Sein or a science in order to manage the economy and its government. Political economy has a tendency for values and aspects of political interests. On the one hand, interests or politics are stronger than economic aspects. The economy Motives are also charged itself by the political motives.

Furthermore, political economy is basically capital or an investment. Capital is the basic capital of infrastructure development. One reflection of the development of political economy is regional economic development. MEA (ASEAN Economic Community) is a regional economic development. Then, Economy politic is Das sullen, is a policy product based on a country's economic conditions, relying on economic law and political economy. Economic politics is an element or element that becomes a tool or political interest, and rationalization of political power. 
So that, the objectives to be achieved, after being prepared through plans are achieved as expected. Therefore, economic politics are an effort of the state in realizing the widest possible prosperity and economic justice for the community, so that people can enjoy developed Economic politics is a way to create prosperity and prosperity for society. Politics and economics are two inseparable parts. Politics is economy, and vice versa. Therefore, to implement an economic concept, a policy (politics) is needed.

Economics law, political economy, and economic politics are the three keys to realizing the country's defense economy. The state will not continue (sustain) if the government does not pay attention to aspects of defense. Therefore, the government as a policy maker must realize the sovereignty of his country. Based on theory of defense economy theory described above, this research is in line with the theory, that the government's interest in realizing public welfare is a mandatory duty of the government. Therefore, if the community is not prosperity, economic growth cannot be realized.

Furthermore, through the development of tourism, is one form of the defense economy. Utilizing the potential possessed by an area, one of which is tourism, in supporting the economic resilience of a region and the country, as well as realizing regional defenses through tourism.

Theory of Entrepreneur. Definition of entrepreneur explained by Schumpeter, Entrepreneur as a person who destroying the existing economics order by introducing new products and services, by creating new forms organizations, or by exploiting new raw material. Furthermore, entrepreneurs are someone who is able to move or convert economic resources from low productivity to high. According to Hisrich-Peters, entrepreneurship is the process of creating something different with value by devoting the necessary time and effort, assuming the accompanying financial, personal satisfaction and independence. Entrepreneurship is a method for creating everything into a product that has added value.

According to Zimmerer, an entrepreneur is a person who create business, with risk, uncertain condition and focus for considering profit with accretion throughout identification every opportunity through resource combination which is needed for getting benefit. Every potential can be utilized as an opportunity to gain profit. According to Prof. Dr. J. Winardi, S.E. , there are some characteristics about someone who has an entrepreneurial spirit, including:

- Internal Control Locus. An entrepreneur has a principle, that they have the ability to determine their own destiny, and are able to control themselves, and move automatically.

- High Energy Level. An entrepreneur has excess energy, they can do anything regardless of time and energy. They will stop if a work or product has been formed or succeeded.

- Tolerance Against Ambiguity. An entrepreneur is ready to accept various risks, uncertainty is a certainty that they must face.

- High Trust. An entrepreneur has complete control over every decision they make. Every decision has risks, but behind every risk, the opportunities they can get.

- Action Oriented. An entrepreneur is an executor, they do not just issue ideas or concepts, ideas and concepts must be carried out in accordance with the plans that have been made.

Entrepreneurial Concept. Entrepreneurs have the concept that creative and innovative thinking is a mindset, in order to solve a problem, or produce something new. How to think of an entrepreneur, see an obstacle, as an opportunity, as well as an opportunity to develop and become a leader in every competition. Furthermore, entrepreneurship has a way of looking at people in general. Sometimes, they can see opportunities, they quickly act, so that they benefit without the general public's awareness. An entrepreneur can be born through professional experience, their environment grows, as well as compelling circumstances.

One example, Walt Disney is a legend in the world of cinema, he is a successful businessman in the entertainment industry. However, the bitter story behind Walt Disney's success, Walt Disney received unfair treatment from his parents. He was locked up for some time, in captivity, he was accompanied by rats. Since that time, Walt Disney has inspired mouse animals, becoming a cartoon character favored by children. The cartoon character was named Mickey Mouse. Until now, Mickey Mouse is 
very popular with children around the world, even adults have a collection of Mickey Mouse dolls. Based on the bitter experience of the past, Walt Disney became a successful businessman today. Furthermore, Colonel Sanders, a fast food businessman namely KFC (Kentucky Fried Chicken), started a business with 1000 failures to do a fast food business. Colonel Sanders did not give up facing the failures he faced. Until now, KFC has outlets in almost all countries in the world. Based on the successful experience of entrepreneurs above, creative and unyielding is a principle that must be held, in order to successfully establish a business. Furthermore, success is achieved, unlike turning a palm. Unfinished sacrifice and effort are the key to success for entrepreneurs.

\section{Research Methodology}

This study uses a qualitative method. Qualitative research is carried out with a descriptive approach. Descriptive qualitative research is a research that seeks to provide solutions or solutions to existing problems based on existing data sources. Research conducted is research that uses qualitative methods, with data collection techniques in the form of interviews, observation and review of documents. The implementation of research related to the topics raised, the researchers chose to use a qualitative approach for the reason that the problems studied could be reviewed, then analyzed and understood in depth.

Efforts made to explore information related to research were carried out by looking at the application of village funds to the object of research. In addition, information was also collected through various sources obtained from the BPM-PPD report, the tourism agency and the village head regarding reports on entrepreneurship-based tourism village development.

The subjects of this study were informants who were directly related to the research and also had competence or expertise in the field and in accordance with data needs. While the object of this study is Pentingsari Village, Umbulharjo, Cangkringan, Sleman Regency, Yogyakarta Special Region (DIY). Data collection techniques in this study, conducting in-depth interviews (in-depth interviews) and collecting related documents obtained online or directly from the resource person. Semistructured interviews are chosen so that researchers can get a lot of data and allow researchers to make spontaneous questions but are still relevant to the topic of the study if the list of interview questions is not sufficient.

After the data collection process is complete, the next step that will be carried out is the analysis of the results of interviews, observations and related documents. These data will be processed in the discussion and analysis process. In the process of discussion and analysis, researchers will use the theory that is the framework of this research. In other words, researchers will combine the findings of important concepts through inductive reasoning to get the most powerful view so that they can form conclusions related to the research topic.

\section{Result and Discussion}

Mr. Doto explained that Pentingsari Tourism Village was established in 2008 and located on the slopes of Mount Merapi with a distance of $12.5 \mathrm{~km}$ from the summit of Mount Merapi and $22.5 \mathrm{~km}$ from the center of Yogyakarta City. Tourism villages are community-based tourist destinations by maintaining local and sustainable wisdom. Important tourism village with the theme "Village of Nature, Culture and Agriculture with Environmental Insights". In accordance with this theme, Pentingsari tourism village offers experience tourism activities in the form of learning about nature, the environment, agriculture, plantations, entrepreneurship, socio-cultural life, various traditional arts and local wisdom that are still firmly rooted in the community with a typical rural atmosphere on the slopes of Mount Merapi.

In 1990, Pentingsari Village was one of the poorest hamlets in the villages on the Merapi Gurung slope, with a relatively low level of economic and community income and a simple village life. This is because access to this region is difficult and conditions of land are infertile. However, with the spirit of mutual cooperation in caring for nature, the environment and local wisdom taught by the 
people before, it has produced results with the abundance of natural wealth, vegetation, produce and the socio-cultural life of rural communities that are maintained. But people's lives are still less open to the outside world.

In the beginning of 2008 villagers began to take small steps to add value to the social, economic and cultural life of the village community, but retained local wisdom and community culture. With various limitations and capitalized on the enthusiasm and support of various parties, a tourism village was built so that the Pentingsari village could advance and align with other villages. The development of this tourism village requires the villagers to have the ability to open themselves up and build positive interactions with outside communities.

Activities promoted in the tourist village of Pentingsari are daily community activities such as farming, raising livestock, and other activities, so that the tourism village is expected to have a tremendous impact on the community to be active as actors and not just as objects. Establishment of tourist villages without material capital but only with enthusiasm by inviting the community together to organize themselves, manage and preserve the environment and have pride in their own village. In addition, tourism village development also cooperates with various parties, both government and private as well as universities to actively participate in building villages

In 2008 the community of Pentingsari Tourism Village could not rely on tourism villages as an effort to raise the level of economic and community income due to limitations in the ability of human resources, supporting facilities and infrastructure, skills and the creation and marketing of tour packages. This year the number of tourists has not reached 1,000 tourists. Whereas in 2009 the Pentingsari Tourism Village received assistance from various parties that provided programs to improve camp facilities and infrastructure such as hall repairs, bathrooms, parking lots, and improved road access. With the existence of this program, it greatly affected the public income because the number of tourists increased significantly, reaching 5,000 tourists in 2009.

In 2010 the Pentingsari Tourism Village was well organized, followed by getting programs and assistance to facilitate HR training, guiding uniforms, adding art, culinary and souvenir facilities. With the PNPM Mandiri Tourism program it was able to accelerate efforts to improve facilities and infrastructure, so Pentingsari had 40 homestays, various agricultural attractions, arts and culture, and services that began to be well organized. However, the development of this tourist village was destroyed by the eruption of Mount Merapi. This also results in not achieving the target of tourists. Tourists this year are less than 9,000 with a target of more than 10,000 tourists.

This eruption disaster also caused damage to existing facilities and infrastructure and took 6 months to restore the trust of the people and tourists that tourism villages could develop again. Natural disasters are not used as an excuse to beg and complain, but with the spirit of togetherness this natural disaster makes the village community stronger and more active in managing the socio-economic life of the community. This is inseparable from the support of government and private parties, such as the support of CSR Programs from BCA and various Community Service Institutions in Universities for village facilities and infrastructure, human resource capacity development and the development of a productive economic community. With a population of 370 people, 127 families, Pentingsari Tourism Village is currently able to empower most community members greater than $70 \%$, with various groups involved, such as homestays (55 units), arts and cultural attractions ( 25 people), guides local / youth tourism (30 people), local culinary (60 people), home industry (20 people), community owned shop (6 units), and security / support staff (30 people).

The villagers are also able to utilize the abandoned village cash land into camping and outbound areas ( $1 \mathrm{ha}$ ) and the Kali Kuning river basin becomes an attractive adventure area for tourists. In addition to collaborating with institutions, Pentingsari Tourism Village communities also collaborate with several parties in the village such as youth farmer groups, plantations, agriculture and peasant women. While cooperation with parties outside the village community such as art groups, breeders' groups, lava tours and village government with village cash land. 
After getting assistance, assistance in developing human resources and tourism facilities from various parties at the level of tourist visits has been stable at 30,000-35,000 people per year and in 2015-2017 with an average income reaching Rp. 150,000 - Rp. 200,000 / month. In a period of 10 years, Pentingsari Tourism Village was able to provide opportunities for people to get additional income and increase the economy without leaving the village, without having to damage the environment, be able to prevent the flow of urbanization for the young generation, empower women's groups and the growth of various productive economic activities.

Daily activities in Pentingsari Village, become a nature therapy, enjoying activities in the village, and forgetting for a moment the routine activities in the office. Transformation The village of Pentingsari became a tourist village, has a similar approach to gun theory regarding tourism development. Gunn's tourism development model, A tired and saturated city community for daily activities in the city requires different activities, to relieve fatigue and fatigue, this is a request. The village of Pentingsari offers a natural activity, with a rural atmosphere, the community can participate as important villagers of Sari, following daily activities in the village. Using a supply and demand approach

Looking from the perspective of the economic concept of defense, tourism activity, activities in Pentingsari Village, generate income for the community. The environment in Pentingsari Village is maintained, due to tourism activities in Pentingsari Village. This is an implementation of the theory of economy defense. Indonesia's national defense system puts society as the main element of the defense.

Pentingsari Village involves local communities in carrying out tourism activities. Therefore, the defense base in Pentingsari Village has strong strength. Local people as the main actors in tourism activities in the village. In addition, economic activity emerged, due to the sale and purchase transaction of handicrafts, as well as various creative products.

Indirectly, the concept of defense economy is carried out by the people of Pentingsari Village through tourism village activities. Pentingsari Tourism Village arises due to the entrepreneurial spirit that arises from the local population. Pentingsari villagers want to change their fate for the better. In the past Pentingsari Village was a poor village.

At present, Pentingsari Village has changed from a poor village to an advanced village. Entrepreneurship creates an obstacle to become an opportunity, to get a profit or profit, especially the village community, through the development of a tourism village through an entrepreneurial base. Therefore, now the Important Village communities have income, and can continue their children to go to school, and higher education.

\section{Conclusion}

Entrepreneurship based on village tourism is one of role model for empowering people and maximizing resource in the village. Poverty in the village is able to erase not only by government policy example: subsidy or government assistance, but also managing village assets with professional handling. Participation society in the village are tremendous leverage for changing of life Pentingsari Village people. Indirectly, village tourism is implementing concept of economics defense. Participation of village society become the strongest defense for Pentingsari Village region.

Internally, Indonesia government must reform its regulation related to the policy for decreasing poverty by entrepreneurship method. Every territory in Indonesia consist of village or small community. Most of them are poor, because of unavailable public facility and access road. The Indonesian government needs to pay attention in suburb region for distributing equality economics for Indonesian people.

\section{References}

Ady, M. M. A. (2015). Findings in Interviews on Motivation of Farmers for the Improvement of Paddy Rice Quality and the Implementation of New Methods of Paddy Rice Production in the 
Chiba Prefecture. 人文社会科学研究第 31 号. Retrieved from https://core.ac.uk/download/pdf/97064981.pdf

Andayani, Ni Luh Henny. (2015). Manajemen Pariwisata. Jakarta: Graha Ilmu

Creswell, John W. . (2015). Penelitian Kualitatif \& Desain Riset Memilih diantara Lima Pendekatan. Yogyakarta : Pustaka Pelajar

Creswell, John W. (2016).Research Design: Pendekatan Metode Kualitatif, Kuantitatif, dan Campuran. Yogyakarta: Pustaka Pelajar

Hunziker and Kraf. (1941).Contributions to tourism education and tourism history. Bern: Federation Suisse du Tourisme

Kementrian Pertahanan RI. (2015). Buku Putih Pertahanan Indonesia. Jakarta: Kementrian Pertahanan RI

Supriatna, Agus. (2017). Pertahanan Nasional dalam Perspektif Ekonomi. Bandung: UNPAD Press Supriyatno, Makmur. (2014). Tentang Ilmu Pertahanan. Jakarta: Yayasan Pustaka Obor

Spillane, James J. (1987). Ekonomi Pariwisata. Surabaya: Kanisius

Tippe, Syarifudin. (2016). Ilmu Pertahanan. Jakarta: Salemba Humanika

Yusgiantoro, Purnomo. (2014). Ekonomi Pertahanan: Teori \& Praktik. Jakarta: Gramedia Pustaka Utama

Regulations No. 10 year 2009 about Tourism

Regulations No. 3 Year 2002 about Defense

UNESCO. (2010). The Power of Culture for Developmet. Journal Of UNESCO

OECD. (2009). The Impact of Culture on Tourism. Journal of OECD

Valeriu and Elena Manuela. (2007). Cultural Tourism and Sustainable Development. Romanian Journal of Economic Forecasting - 1, 2007 